\title{
INTERACTION BETWEEN RESISTANT TOMATO GENOTYPES AND PLANT EXTRACTS ON Bemisia tabaci (GENN.) BIOTYPE B
}

\author{
Edson Luiz Lopes Baldin ${ }^{1 *}$; José Djair Vendramim²; André Luiz Lourenção ${ }^{3}$ \\ ${ }^{1}$ UNESP/FCA - Depto. de Produção Vegetal - Defesa Fitossanitária, C.P. 237 - 18603-970 - Botucatu, SP - Brasil. \\ ${ }^{2}$ USP/ESALQ - Depto. de Entomologia, Fitopatologia e Zoologia Agrícola, C.P. 9 -13418-900 - Piracicaba, SP - \\ Brasil. \\ ${ }^{3}$ IAC - Setor de Entomologia, C.P. 28 - 13001-970 - Campinas, SP - Brasil. \\ *Corresponding author <elbaldin@fca.unesp.br>
}

ABSTRACT: The tomato (Lycopersicon spp.) productivity is severely reduced by attack of several insects and microorganisms. It is economically one of the most important crops that has been extensively cultivated in the Americas. Therefore, assays were performed in the greenhouse and the laboratory to evaluate the possible interaction between resistant tomato genotypes and plant extracts on the control of the pest Bemisia tabaci Gennadius (Hemiptera: Aleyrodidae) biotype B. This evaluation was performed for genotypes IAC-Santa Clara, PI-134417, LA-716, PI-134418, and PI-127826, and aqueous extracts from seeds of Azadirachta indica A. de Jussieu (Rutales: Meliaceae), branches and leaves of Trichilia pallida Swartz (Rutales: Meliaceae). In the greenhouse, spraying with extracts from seeds of A. indica, and leaves and branches of T. pallida reduced whitefly attraction with IAC-Santa Clara; on PI-134417, LA-716, PI-134418, and PI-127826 the extracts did not affect the attractiveness to the $B$. tabaci biotype B. Extracts from A. indica seeds and T. pallida leaves and branches reduced oviposition on IAC-Santa Clara; extracts from T. pallida branches reduced oviposition on PI-134417, PI-134418, and PI-127826, while the extract from A. indica seeds reduced oviposition in PI-127826. The extracts did not affect oviposition on LA-716. In the laboratory, the extracts increased the mortality of nymphs on the genotypes. The "genotype $\times$ extract" interaction was significant, indicating an addictive effect between resistant genotypes and plant extracts on whitefly control.

Key words: Aleyrodidae, silverleaf whitefly, host plant resistance, botanical insecticide

\section{INTERAÇÃO DE GENÓTIPOS RESISTENTES DE TOMATEIRO E EXTRATOS VEGETAIS SOBRE Bemisia tabaci (GENN.) BIÓTIPO B}

RESUMO: O tomate (Lycopersicon spp.) é uma das hortaliças mais importantes do mundo em termos econômicos e tem sido extensivamente cultivado nas Américas há séculos. Entretanto, a produtividade poderia ser mais alta se ela não fosse suscetível a ataques de insetos e microorganismos. Foram realizados ensaios em casa-de-vegetação e laboratório visando avaliar a possível interação de genótipos de tomateiro resistentes e extratos vegetais no controle de Bemisia tabaci Gennadius (Hemiptera: Aleyrodidae) biótipo B. Utilizaram-se os genótipos IAC-Santa Clara, PI-134417, LA-716, PI-134418 e PI-127826 e extratos aquosos à base de sementes de Azadirachta indica A. de Jussieu (Rutales: Meliaceae), ramos e folhas de Trichilia pallida Swartz (Rutales: Meliaceae). Em casa-de-vegetação, a pulverização com extratos de sementes de A. indica, folhas e ramos de T. pallida reduziu a atração da mosca-branca para o genótipo IAC-Santa Clara; em PI-134417, LA-716, PI-134418 e PI-127826, a presença dos extratos não afetou a atratividade a B. tabaci biótipo B. Extratos de sementes de A. indica e de folhas e ramos de T. pallida reduziram a oviposição em IAC-Santa Clara. O extrato de ramos de $T$. pallida reduziu a oviposição em PI-134417, PI-134418 e PI-127826; enquanto que o extrato de sementes de $A$. indica reduziu a oviposição em PI-127826. Já em LA-716, a presença dos extratos não afetou a oviposição. No laboratório, a presença dos extratos vegetais aumentou a mortalidade de ninfas nos genótipos. A interação genótipo x extrato foi significativa, indicando um efeito aditivo pelo uso de genótipos resistentes e extratos vegetais no controle da mosca-branca.

Palavras-chave: Aleyrodidae, mosca-branca, resistência de plantas, inseticida botânico

\section{INTRODUCTION}

Tomato (Lycopersicon spp.) is economically one of the most important vegetables and has been extensively cultivated in the Americas for centuries (Polston \& Anderson, 1999). Its productivity could 
even be higher if this crop would not be susceptible to the attack of a large number of insects and microorganisms (França \& Castelo Branco, 1987).

Among the insects that attack the crop, the silverleaf whitefly Bemisia tabaci Gennadius (Hemiptera: Aleyrodidae) biotype B is worth noting, especially, because of the geminivirus transmission during the feeding process (Oliveira \& Silva, 1997; Carneiro et al., 1999; Oliveira \& Farias, 2000). Whiteflies cause symptoms such as plant yellowing and marked stunting, in addition to shriveling of terminal leaves that significantly compromises yield (Brown \& Bird, 1992; Brown, 1994).

The incidence of geminivirus transmitted by $B$. tabaci biotype $\mathrm{B}$ is very high in tomato-producing areas of Florida, the Caribbean, Mexico, Venezuela, and Brazil, causing devastating economic consequences (Polston \& Anderson, 1999). In addition, diseases caused by geminivirus, such as the tomato yellow leaf curl virus (TYLCV) have reduced tomato yield by 40 to $70 \%$ in Mediterranean countries (Villas Boas et al., 1997). In Brazil, the tomato yellow vein streak virus (TYVSV), a geminivirus described by Faria et al. (1997), affects tomato crops and is also transmitted by B. tabaci biotype B (Matos et al., 2003).

To date, the most frequently used whitefly control method is chemical, via insecticidal sprays. However, the harmfulness of these products on the environment, extermination of natural enemies, and rapid development of resistance by insects (Prabhaker et al., 1985; Stansly \& Schuster, 1992; Oliveira \& Silva, 1997) led to alternative control methods, such as the use of resistant genotypes (Toscano et al., 2002; Fancelli et al., 2003; Baldin et al., 2005) and plant extracts with insecticidal and/or "insectistatic" action (Cunha et al., 2005; Bogorni \& Vendramim, 2005). Most of these studies however mainly focused the evaluation of the two afore mentioned control tactics individually, without exploiting the association between methods as an additional factor.

Because the biological development of $B$. tabaci biotype $\mathrm{B}$ is affected in individuals reared on resistant genotypes (Baldin et al., 2005), it is expected that a generation of insects from these hosts will have their biological and/or behavioral conditions altered in relation to insects obtained from a more suitable plant host. Therefore, the hypothesis that insect populations are negatively affected by the host will be more sensitive to the application of insecticidal plant extracts, which would confirm the addictive effect of the association between both management tactics.

The objectives of this research were to confirm the resistance mechanisms of some selected tomato genotypes (Baldin et al., 2005), as well as to evaluate a possible interaction between these mechanisms and extracts of some plants of the Meliaceae family to control the whitefly B. tabaci biotype B.

\section{MATERIAL AND METHODS}

This research was conducted in a greenhouse and a laboratory during the summer (December to March) of 2005 in Fernandópolis (20 $0^{\circ} 17^{\prime} \mathrm{S}, 5^{\circ} 14^{\prime} \mathrm{W}$, and 535m altitude), SP, Brazil. A colony of B. tabaci biotype B was maintained inside metal cages $(2 \times 2.5$ $\times 2 \mathrm{~m}$ ) with the top part covered with plastic and shade cloth and the sides lined with white anti-aphid mesh, with weekly addition and removal of soybean, poinsettia, and collard green plants.

Obtaining plant extracts - Aqueous extracts were prepared from leaves and branches of Trichilia pallida Swartz (Rutales: Meliaceae) and neem seeds Azadirachta indica A. de Jussieu (Rutales: Meliaceae). Except for neem, all plant materials were oven dried at $40^{\circ} \mathrm{C}$ for 2 days and than ground to powder in an electric knife mill. The powders were stored separately by species and plant structure in dark, hermetically sealed containers. The extracts were prepared mixing the powder of each material ( $2.0 \mathrm{~g}$ ) with distilled water $(100 \mathrm{~mL})$ using a stirrer. The resulting suspensions were maintained in flasks for $24 \mathrm{~h}$, allowing the complete extraction of water-soluble compounds. Next, the solutions were filtered through a fine fabric (voile), producing the aqueous extracts at $2.0 \%$ (weight/volume).

Adult attractiveness and oviposition - The attractiveness and non-preference for oviposition of $B$. tabaci biotype $\mathrm{B}$ were evaluated in a free-choice test in the greenhouse $\left(\mathrm{T}=27.4 \pm 6.1^{\circ} \mathrm{C}\right.$; $\mathrm{RH}=72.6 \pm$ $13.6 \%$; natural photoperiod), using ten replicates in a $5 \times 4$ factorial completely randomized design, with 20 treatments. The two factors were genotypes (five levels) and extracts (four levels: three extracts and control). Initially, genotypes IAC-Santa Clara ( $L$. esculentum), PI-134417 (L. hirsutum f. glabratum), LA-716 (L. pennelli), PI-134418 (L. hirsutum f. glabratum), and PI-127826 (L. hirsutum) were sown in expanded polyethylene trays containing agricultural substrate. Twenty days after emergence, seedlings were transplanted to 5-L pots and received water as needed and recommended fertilization (Raij et al., 1997). Each plot in this assay consisted of one pot containing one plant. Fifteen days after transplanting, the plants were sprayed $(150 \mathrm{~mL})$ according to the four treatments using a hand mister, as follows: two aqueous extracts from T. pallida leaves and branches; one aqueous extract from $A$. indica seeds, and a control 
(water). Fifteen minutes after spraying, the pots containing tomato genotypes were randomly distributed in a circle inside the cages. A proportion of 100 unsexed whitefly adults per pot were then released at the floor in the central part of the cage. Attractiveness in the different genotypes was evaluated $24 \mathrm{~h}$ after the initial infestation. Using a mirror, the number of adults present on the abaxial surface of three previously marked leaflets (upper, medium, and lower thirds) was counted.

To determine oviposition non-preference three days after infestation, another three previously marked leaflets (upper, medium, and lower thirds) were removed from the plants and taken to the laboratory, where the number of eggs on the abaxial surface of each leaflet was counted with the aid of a stereoscopic microscope. After the count, the area of each leaflet was measured with a LI-COR (LAI 3000A) leaf area meter. Three readings were made per leaflet, and the average of these observations was considered as leaflet area. The number of eggs $\mathrm{cm}^{-2}$ on each leaflet was then calculated.

Interaction between resistant genotypes and plant extracts - Pre-selected resistant genotypes PI-134417, LA-716, PI-134418, and PI-127826 (Baldin et al., 2005), and the susceptible genotype IAC-Santa Clara were seeded in pots inside a greenhouse $(\mathrm{T}=26.8 \pm$ $5.3^{\circ} \mathrm{C} ; \mathrm{RH}=69.0 \pm 11.9 \%$; natural photoperiod). When the plants were 35 days old, two pots/genotype were infested with 300 adults of $B$. tabaci biotype B from the colony. After $72 \mathrm{~h}$, the adult insects were removed and the cages remained covered to prevent the entry of other whiteflies. The entire immature stage was monitored. Upon emergence, the newly-emerged adults were removed from the plant for testing.

Three leaflets (upper, medium, and lower third) from each of four plants of each genotype, containing plants approximately 35 days of age were kept separate in the laboratory $\left(\mathrm{T}=25 \pm 2^{\circ} \mathrm{C}\right.$; $\mathrm{RH}=70 \pm$ $10 \%$; photophase $=12 \mathrm{~h}$ ). Cages constructed of voile fabric $(10 \times 15 \mathrm{~cm})$ were connected and 50 unsexed adult $B$. tabaci biotype $B$ were released inside each cage. Infestation was maintained for $24 \mathrm{~h}$. After that period, the insects were removed and 50 viable eggs/ leaflet were maintained. In this assay, each leaflet represented one replicate (three per genotype), consisting of 50 sample units (50 eggs). Three days after the nymphs hatched, the leaflets of each genotype were sprayed with the three above-mentioned extracts and water. Nymphal mortality was observed for five days after the sprays. The experiment was conducted in a completely randomized design using the same factorial arrangement already described.

Statistical analysis - Data were submitted to analysis of variance by $\mathrm{F}$ test, and means were compared by the Tukey test $(P \leq 0.05)$ using the ESTAT (2.0) statistical program.

\section{RESULTS AND DISCUSSION}

Adult attractiveness and oviposition. The whitefly counts on plants after spraying with distilled water (Table 1), show that genotype IAC-Santa Clara presented the highest mean of insects, differing from PI127826, PI-134417, PI-134418, and LA-716, which were comparatively less attractive. These results agree with those obtained by Baldin et al. (2005), in which PI-134417, PI-134418, and LA-716 had shown a less attractive behavior, and support the hypothesis that spraying with distilled water does not affect attractiveness in this type of assay.

When sprayed with neem seed extracts (Table 1), the leaflets of genotype LA-716 did not attract whitefly adults, differing from IAC-Santa Clara, which was the most attractive; the other plants had moderate counts. After spraying with T. pallida leaf extracts, the genotype LA-716 leaflets were the least attractive, differing from IAC-Santa Clara and PI-134417, which showed a higher number of insects. Genotype LA-716 was also the least attractive when the leaflets were

Table 1 - Mean number ( \pm SE) of B. tabaci biotype B adults $24 \mathrm{~h}$ after infestation on three leaflets of tomato genotypes sprayed with selected plant extracts.

\begin{tabular}{lcccc}
\hline \multirow{2}{*}{ Genotype } & \multicolumn{4}{c}{ Extract } \\
\cline { 2 - 5 } & Distilled water & A. indica (seeds) & T. pallida (leaves) & T. pallida (branches) \\
\hline IAC-Sta Clara & $8.2 \varnothing 2.10 \mathrm{aA}$ & $1.7 \varnothing 0.38 \mathrm{aB}$ & $2.9 \varnothing 0.76 \mathrm{aB}$ & $2.1 \varnothing 0.38 \mathrm{aB}$ \\
PI-134417 & $1.6 \varnothing 0.27 \mathrm{bcA}$ & $0.9 \varnothing 0.50 \mathrm{abA}$ & $1.4 \varnothing 0.34 \mathrm{abA}$ & $1.0 \varnothing 0.24 \mathrm{abA}$ \\
LA-716 & $0.3 \varnothing 0.10 \mathrm{cA}$ & $0.0 \varnothing 0.00 \mathrm{bA}$ & $0.2 \varnothing 0.11 \mathrm{cA}$ & $0.2 \varnothing 0.13 \mathrm{bA}$ \\
PI-134418 & $1.4 \varnothing 0.65 \mathrm{bcA}$ & $0.8 \varnothing 0.25 \mathrm{abA}$ & $1.0 \varnothing 0.45 \mathrm{bcA}$ & $0.9 \varnothing 0.53 \mathrm{abA}$ \\
PI-127826 & $1.9 \varnothing 0.33 \mathrm{bA}$ & $0.6 \varnothing 0.18 \mathrm{abA}$ & $1.3 \varnothing 0.28 \mathrm{abcA}$ & $1.0 \varnothing 0.24 \mathrm{abA}$ \\
\hline
\end{tabular}

Means followed by the same lower case letter in the column or upper case letter in the row do not differ (Tukey test, $P \leq 0.05$ ); CV (\%) $=29.48$. Original data. For analysis, data were transformed to $(x+0.5)^{1 / 2}$. 
sprayed with T. pallida branch extract, differing from IAC-Santa Clara. In a similar study aimed at observing B. tabaci attraction to bean plants sprayed with plant extracts, Gómez et al. (1997) evaluated 27 plant species and verified that even though no material was considered repellent, low attraction occurred for plants sprayed with extracts from Ruta graveolens Linneu (Sapindales: Rutaceae), Cymbopogon citratus (D.C.) Stapf (Poales: Poaceae), and Gliricidia sepium (Jacq.) Steud (Fabales: Fabaceae).

There was a significant $(\mathrm{F}=2.47 ; P<0.05)$ genotype $\times$ extract interaction for IAC-Santa Clara. The number of insects on the plants decreased in the presence of plant extracts in relation to distilled water (Table 1). The fact that the interaction was not significant for the other genotypes suggests that the morphological and/or chemical characteristics naturally present in the leaflets of these genotypes are sufficient to make them less attractive to the insect, regardless of the presence of plant extracts. In this respect, Larew \& Lock (1990) suggested that whitefly adults are more easily repelled by tactile stimuli than by the presence of volatile compounds, which would explain the results obtained with these genotypes in the present assay.

Based on whitefly oviposition on genotypes sprayed with plant extracts (Table 2), in the presence of distilled water, the leaflets of all genotypes received fewer eggs then those of IAC-Santa Clara, while there were no eggs on LA-716. No differences in oviposition were detected between leaflets of different genotypes when sprayed with extracts from neem seeds. When sprayed with extracts prepared from T. pallida leaves, the IAC-Santa Clara leaflets presented more eggs as compared with PI-134418 and LA-716, which had the fewest number of eggs. When sprayed with the extract from T. pallida branches, all genotypes were different from IAC-Santa Clara, the most oviposited (Table 2). In this assay, there was a significant $(\mathrm{F}=2.54 ; P<0.05)$ genotype $\times$ extract interaction for genotypes IAC-Santa Clara, PI-134417, PI-
134418, and PI-127826. Consequently, oviposition on IAC-Santa Clara leaflets was reduced in the presence of plant extracts, especially those prepared from neem seeds; on genotypes PI-134417 and PI-134418, the leaflets had few eggs in the presence of the extract from T. pallida branches. On PI-127826, the fewest number of eggs were observed for leaflets sprayed with neem seeds and T. pallida branches.

To evaluate the effects of plants with insecticidal activity on B. tabaci oviposition, Gómez et al. (1997) did not obtain eggs when bean plants were sprayed with extracts from Eucalyptus deglupta, $R$. graveolens, and G. sepium. Genotype LA-716 leaflets did not receive eggs, regardless of the nature of the sprayed extract (Table 2), suggesting that their morphological makeup, rich in glandular trichomes, may be their most powerful source of resistance against whitefly oviposition, as reported by several authors (Channarayappa et al., 1992, Barten et al., 1994, Fancelli et al., 2003). The resistance mechanism (antixenosis) in Lycopersicon spp. is mediated by acylsugars found in type IV glandular trichomes (Fancelli \& Vendramim, 2002; Toscano et al., 2002).

Interaction between resistant genotypes and plant extracts - Mortality percentages of nymphs reared on the respective genotypes (Table 3), show that in the distilled water treatment, the lowest percentage was obtained in IAC-Santa Clara, differing from PI-134417, PI134418, and especially PI-127826, which presented the highest mortality percentage. These data support results obtained by Baldin et al. (2005), which indicated the occurrence of non-preference for feeding and/or antibiosis on these genotypes. In the presence of extract from neem seeds, genotype PI-127826 resulted in the highest mortality percentage obtained in the experiment (above 90\%), differing from the percentages obtained on PI-134417 and IAC-Santa Clara. When sprayed with leaves and branches of T. pallida, the highest mortality indices were obtained in geno-

Table 2 - Mean number ( \pm SE) of B. tabaci biotype B eggs $/ \mathrm{cm}^{2} 72 \mathrm{~h}$ after infestation on three leaflets of tomato genotypes sprayed with selected plant extracts.

\begin{tabular}{lcccc}
\hline \multirow{2}{*}{ Genotype } & \multicolumn{5}{c}{ Extract } \\
\cline { 2 - 5 } & Distilled water & A. indica (seeds) & T. pallida (leaves) & T. pallida (branches) \\
\hline IAC-Sta Clara & $6.7 \varnothing 2.07 \mathrm{aA}$ & $1.0 \varnothing 0.23 \mathrm{aC}$ & $3.3 \varnothing 1.08 \mathrm{aB}$ & $2.5 \varnothing 0.77 \mathrm{aBC}$ \\
PI-134417 & $0.9 \varnothing 0.36 \mathrm{bcAB}$ & $0.1 \varnothing 0.03 \mathrm{aAB}$ & $1.3 \varnothing 0.54 \mathrm{abcA}$ & $0.0 \varnothing 0.00 \mathrm{bB}$ \\
LA-716 & $0.0 \varnothing 0.00 \mathrm{cA}$ & $0.0 \varnothing 0.00 \mathrm{aA}$ & $0.0 \varnothing 0.00 \mathrm{cA}$ & $0.0 \varnothing 0.00 \mathrm{bA}$ \\
PI-134418 & $1.3 \varnothing 0.61 \mathrm{bA}$ & $0.1 \varnothing 0.07 \mathrm{aAB}$ & $0.3 \varnothing 0.17 \mathrm{bcAB}$ & $0.1 \varnothing 0.03 \mathrm{bB}$ \\
PI-127826 & $2.2 \varnothing 0.37 \mathrm{bA}$ & $0.5 \varnothing 0.08 \mathrm{aB}$ & $1.4 \varnothing 0.24 \mathrm{abAB}$ & $0.5 \varnothing 0.11 \mathrm{bB}$ \\
\hline
\end{tabular}

Means followed by the same lower case letter in the column or upper case letter in the row do not differ (Tukey test, $P \leq 0.05$ ); $\mathrm{CV}$ (\%) $=31.27$. Original data. For analysis, data were transformed to $(x+0.5)^{1 / 2}$. 
Table 3 - Mean percentage $( \pm$ SE) nymphal mortality of B. tabaci biotype B obtained on leaflets of tomato genotypes, five days after spraying with selected plant extracts.

\begin{tabular}{lclcc}
\hline \multirow{2}{*}{ Genotype } & \multicolumn{5}{c}{ Extract } \\
\cline { 2 - 6 } & Distilled water & A. indica (seeds) & T. pallida (leaves) & T. pallida (branches) \\
\hline IAC-Sta Clara & $6.8 \varnothing 1.00 \mathrm{cC}$ & $71.3 \varnothing 1.88 \mathrm{cA}$ & $52.1 \varnothing 2.89 \mathrm{bB}$ & $64.3 \varnothing 1.74 \mathrm{bA}$ \\
PI-134417 & $22.9 \varnothing 2.23 \mathrm{bD}$ & $85.4 \varnothing 1.21 \mathrm{bA}$ & $57.3 \varnothing 4.49 \mathrm{abC}$ & $71.6 \varnothing 0.96 \mathrm{bB}$ \\
PI-134418 & $25.6 \varnothing 2.63 \mathrm{bD}$ & $87.6 \varnothing 1.92 \mathrm{abA}$ & $58.8 \varnothing 0.95 \mathrm{abC}$ & $72.8 \varnothing 2.11 \mathrm{abB}$ \\
PI-127826 & $35.2 \varnothing 2.02 \mathrm{aD}$ & $91.9 \varnothing 1.24 \mathrm{aA}$ & $66.1 \varnothing 3.59 \mathrm{aC}$ & $80.8 \varnothing 0.84 \mathrm{aB}$ \\
\hline
\end{tabular}

Means followed by the same lower case letter in the column or upper case letter in the row do not differ (Tukey test, $P \leq 0.05)$; CV (\%) $=4.88$. Original data. For analysis, data were transformed to arc sine $(x+0.5)^{1 / 2}$.

type PI-127826, differing from IAC-Santa Clara (leaves and branches) and PI-134417 (branches), which resulted in the lowest mortality percentages (Table 3). Genotype LA-716 was excluded from this assay because there was no oviposition on the leaflets.

The mortality percentages obtained with the extracts from neem seeds and T. pallida branches and leaves are similar to those observed by Souza \& Vendramim (2000; 2001), which indicated that these materials are effective for the control of eggs and nymphs of $B$. tabaci biotype $B$.

In the last experiment, there was a significant $(\mathrm{F}=3.48 ; P<0.05)$ genotype $\times$ extract interaction for all genotypes (Table 3), revealing that the three plant extracts increased the mortality of second-generation B. tabaci nymphs, as compared with distilled water in the four genotypes evaluated (Figure 1). This supports the addictive effect of genotype resistance and plant extracts with some insecticidal activity for the control of the B. tabaci biotype B whitefly.

The addictive effect was repported by Vendramim \& Thomazini (2001), which verified a lower percentage of larval viability of Tuta absoluta Meyrick (Lepidoptera: Gelechiidae), when associated the resistant tomato genotype IPA-5 with extracts of leaves and branches from T. pallida. In another assay, the associated use of the maize resistant genotype CM-23 with extracts of branches from T. pallida increased the larval mortality of Spodoptera frugiperda J. E. Smith (Lepidoptera: Noctuidae), when compared to the mortality obtained with the different tactics separately (Torrecillas \& Vendramim, 2001).

The individual effectiveness of the two whitefly control methods was demonstrated, as well as the potentiation of the effect when both tactics are used together. Within the IPM philosophy and the sustainable management of crops, it would be more advantageous to use both tactics together. However, considering the time required to obtain resistant genotypes with commercial characteristics, and the fact that the present work also revealed the effectiveness of using

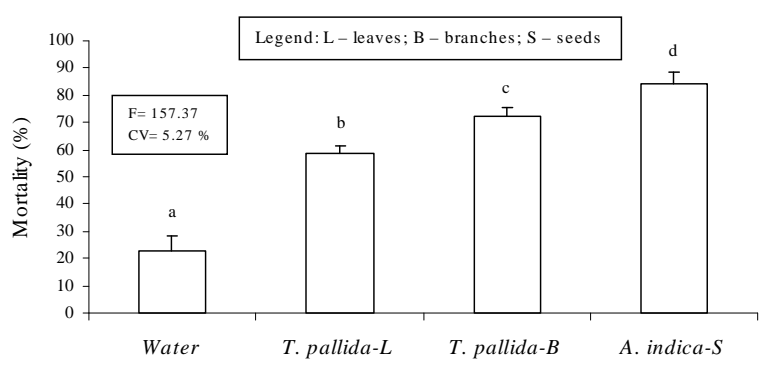

Figure 1- Mean mortality ( \pm SE) of second-generation $B$. tabaci biotype B nymphs obtained on leaflets of tomato plant genotypes, five days after spraying the corresponding tomato genotypes with plant extracts.

insecticidal plants to control this pest, the latter tactic may be recommended, though individually, because, in this case, the source material to obtain extracts can be easily found, creating a simpler alternative, therefore more accessible to small growers.

\section{ACKNOWLEDGMENTS}

To FAPESP, for grant $\mathrm{N}^{\circ}$ 02/05460-5.

\section{REFERENCES}

BALDIN, E.L.L.; VENDRAMIM, J.D.; LOURENÇÃO, A.L. Resistência de genótipos de tomateiro à mosca-branca Bemisia tabaci (Gennadius) biótipo B (Hemiptera: Aleyrodidae). Neotropical Entomology, v.34, p.435-441, 2005.

BARTEN, J.H.M.; THOME, C.H.; STEVENS, M.R.; SCHUSTER, D.J.; SCOTT, J.W.; CHAMBLISS, O.L. Evaluating resistance in tomato to the silverleaf whitefly, Bemisia argentifolii. Phytoparasitica, v.22, p.330-331, 1994.

BOGORNI, P.C.; VENDRAMIM, J.D. Efeito subletal de extratos aquosos de Trichilia spp. sobre o desenvolvimento de Spodoptera frugiperda (J.E. Smith) (Lepidoptera: Noctuidae) em milho. Neotropical Entomology, v.34, p.311-317, 2005.

BROWN, J.K. Current status of Bemisia tabaci as a plant pest and virus vector in agroecosystems worldwide. Plant Protection Bulletin, v.42, p.3-32, 1994.

BROWN, J.K.; BIRD, J. Whitefly-transmitted geminiviruses and associated disorders in Americas and the Caribbean Basin. Plant Disease, v.76, p.220-225, 1992.

CARNEIRO, J.S.; HAJI, F.N.P.; BLEICHER, E.; SILVA, P.H.S.; ALENCAR, J.A.; ARAÚJO, L.H.A.; BARBOSA, F.R. Uma proposta de manejo - I. Granja, v.55, p.124-125, 1999. 
CHANNARAYAPPA, S.G.; MUNIYAPPA, V.; FRIST, R.H. Resistance of Lycopersicon species to Bemisia tabaci, a tomato leaf curl virus vector. Canadian Journal of Botany, v.70, p.2184-2192, 1992.

CUNHA, U.S.; VENDRAMIM, J.D.; ROCHA, W.C.; VIEIRA, P.C. Potencial de Trichilia pallida Swartz (Meliaceae) como fonte de substâncias com atividade inseticida sobre a traça do tomateiro, Tuta absoluta (Meyrick) (Lepidoptera: Gelechiidae). Neotropropical Entomology, v.34, p.667-673, 2005.

FANCELLI, M. VENDRAMIM, J.D. Development of Bemisia tabaci (Gennadius, 1889) biotype B on Lycopersicon spp. genotypes. Scientia Agricola, v.59, p.665-669, 2002.

FANCELLI, M.; VENDRAMIM, J.D.; LOURENÇÃO, A.L.; DIAS, C.T.S. Atratividade e preferência para oviposição de Bemisia tabaci (Gennadius) (Hemiptera: Aleyrodidae) biótipo B em genótipos de tomateiro. Neotropical Entomology, v.32, p.319328, 2003.

FARIA, J.C.; SOUZA-DIAS, J.A.C.; SLACK, S.A.; MAXWELL, D.P. A new geminivirus associated with tomato in the State of São Paulo, Brazil. Plant Disease, v.81, p.423, 1997.

FRANÇA, F.; CASTELO BRANCO, M. Resistência varietal a insetos e ácaros em hortaliças. Horticultura Brasileira, v.5, p.8-11, 1987.

GÓMEZ, P.; CUBILLO, D.; MORA, G.A.; HILJE, L. Evaluación de possibles repelentes de Bemisia tabaci: II. Extractos vegetales. Manejo Integrado de Plagas, v.46, p.17-25, 1997.

LAREW, H.G.; LOCKE, J.C. Repellency and toxicity of a horticultural oil against whiteflies on chrysanthemum. HortScience, v.25, p.1406-1407, 1990.

MATOS, E.S.; SIQUEIRA, W.J.; LOURENÇÃO, A.L.; MELO, A.M.T.; SAWASAKI, H.E.; SOUZA-DIAS, J.A.C.; COLARICCIO, A. Resistência de genótipos de tomateiro a um isolado de geminivirus do cinturão verde de Campinas, São Paulo. Fitopatologia Brasileira, v.28, p.159-165, 2003.

OLIVEIRA, M.R.V.; SILVA, O.L.R. Prevenção e controle da mosca-branca Bemisia argentifolii (Hemiptera: Aleyrodidae). Brasília: Ministério da Agricultura e do Abastecimento, Departamento de Defesa e Inspeção Vegetal, 1997. 16p. (Alerta Fitossanitário, 1).

OLIVEIRA, M.R.V.; FARIAS, M.R.A. A mosca-branca assusta. Granja, v.56, p.12-24, 2000.
POLSTON, J.E.; ANDERSON, P.K. Surgimiento y distribución de geminivirus transmitidos por mosca blanca en tomate en el Hemisferio Occidental. Manejo Integrado de Plagas, v.53, p.24-42, 1999.

PRABHAKER, N.; COUDRIET, D.L.; MEYER-DIRK, D.E. Insecticide resistance in the sweetpotato-whitefly Bemisia tabaci (Homoptera: Aleyrodidae). Journal of Economic Entomology, v.78, p.748-752, 1985.

RAIJ, B.; CANTARELLA, H.; QUAGGIO, J.A.; FURLAN, A.M.C. Recomendações de adubação e calagem para o estado de São Paulo. Campinas: Instituto Agronômico; Fundação IAC, 1997. 285p. (Boletim Técnico, 100)

SOUZA, A.P.; VENDRAMIM, J.D. Atividade ovicida de extratos aquosos de meliáceas sobre a mosca-branca Bemisia tabaci (Gennadius) em tomateiro. Scientia Agricola, v.72, p.159170, 2000.

SOUZA, A.P.; VENDRAMIM, J.D. Atividade inseticida de extratos aquosos de meliáceas sobre a mosca-branca Bemisia tabaci (Genn.) biótipo B (Hemiptera: Aleyrodidae). Neotropical Entomology, v.30, p.133-137, 2001.

STANSLY, P.A.; SCHUSTER, D.J. The sweet-potato whitefly and integrated pest management of tomato. Gainesville: University of Florida, Florida Tomato Institute, 1992. p.5474. (Vegetal Crops Special Series, SS-HSO-001).

TORRECILLAS, S.M.; VENDRAMIM, J.D. Extratto aquoso de ramos de Trichilia pallida e o desenvolvimento de Spodoptera frugiperda em genótipos de milho. Scientia Agricola, v.58, p.27-31, 2001.

TOSCANO, L.C.; BOIÇA JR., A.L.; MARUYAMA, W.I. Nonpreference of whitefly for oviposition in tomato genotypes. Scientia Agricola, v.59, p.677-681, 2002.

VENDRAMIM, J.D.; THOMAZINI, A.P.B.W. Traça Tuta absoluta (Meyrick) em cultivares de tomateiro tratadas com extratos aquosos de Trichilia pallida Swartz. Scientia Agricola, v.58, p.607-611, 2001.

VILLAS BÔAS, G.L.; FRANÇA, F.; AVILA, A.C.; BEZERRA, I.C. Manejo integrado da mosca-branca Bemisia argentifolii. Brasília: EMBRAPA, 1997. 11p. (Circular Técnica, 9).

Received September 13, 2006

Accepted June 22, 2007 